\title{
GREEN INFRASTRUCTURE IMPLEMENTATION PROGRAMMES AT NATIONAL LEVEL: CASE STUDY “NATIONAL PROJECT - SUPPORT OF BIODIVERSITY WITH GREEN INFRASTRUCTURE ELEMENTS IN MUNICIPALITIES OF SLOVAKIA"
}

\author{
Denisa HALAJOVÁ*, Peter HALAJ \\ Slovak University of Agriculture in Nitra, Nitra, Slovakia
}

\begin{abstract}
EU-wide strategy promotes the deployment of green infrastructure across Europe. Integrating green infrastructure in spatial planning, policy and strategy development at regional/national levels is the task of each EU member state. The aim of this article is to give an example and evaluate one of the ongoing projects at national level, namely National project - Support of Biodiversity with Green Infrastructure Elements in Municipalities of Slovakia "Green municipalities of Slovakia". The aim of the national project is to implement green infrastructure at local level through vegetation elements in order to maintain and restore biodiversity and ecosystems outside of protected areas Natura 2000. The programme supporting tree planting in rural municipalities is an important tool for the creation of basic elements of green infrastructure throughout Slovakia. As part of the national program, an implementation plan for 6 municipalities in Slovakia in 2020 is proposed. Subsequently, the implementation projects in terms of the use of vegetation in different categories of green spaces, types of vegetation, representation of tree species, including costs and benefits, are proposed. Based on the results, the potential and limits of the programme and specific suggestions for its further use are set. In 6 municipalities, a total of 17 suitable localities were selected for the project, which is an average of 2.83 localities per municipality. A total of 467 woody plants individuals were proposed, representing a total of 19 woody plants species. The total cost of planting is an average of $€ 12,601.10$ per municipality, $€ 7,312.05$ per ha of area, and $€ 161.90$ per single tree. The average number of trees per ha is 45.15 individuals and per each municipality it is 77.83 trees. In the conclusions, a potential risk of the programme regarding the subsequent maintenance of trees, which is not funded under the program, is highlighted.
\end{abstract}

Keywords: tree, biodiversity, rural municipalities, green spaces

Green infrastructure is a strategically planned network of natural and semi-natural areas with other environmental features designed and managed to deliver a wide range of ecosystem services such as water purification, air quality and space for recreation and climate mitigation and adaptation (European Commission, 2013). This network of green (land) and blue (water) spaces can improve environmental conditions and therefore citizens' health and quality of life (European Commission, 2013). We can distinguish between conventional and unconventional components of the green infrastructure: the most conventional elements of the urban green infrastructure are public parks and gardens, green squares, street greenery, green spaces at housing estates and other green spaces or greenery elements and the unconventional components, for example rooftop gardens or green roofs; vertical greenery or green walls; or the so-called rain gardens etc. (Tóth, Halajová and Halaj, 2015). On May 6, 2013, the Commission adopted an EU-wide strategy promoting investments in green infrastructure to restore the health of ecosystems, ensure that natural areas remain connected together, and allow species to thrive across their entire natural habitat, so that nature keeps on delivering its many benefits to us. The strategy promotes the deployment of green infrastructure across Europe (European
Commission, 2013). Integrating green infrastructure in spatial planning, policy and strategy development at regional/national levels is the task of each EU member state. At the national level of Slovakia, these tasks are currently fulfilled within the Operational Programme Quality of Environment, approved by the European Commission on October 28, 2014. The programme aims to support the achievement of the Europe 2030 strategy objectives for smart, sustainable and inclusive growth in all regions of Slovakia. The main objective is to promote the sustainable and efficient use of natural resources, ensure environmental protection, actively adapt to climate change and promote energy efficiency and low-carbon economy. Within the different priority axes, the Operational Programme Quality of Environment is focused, for example, on the elaboration of documents of regional and local territorial systems of ecological stability, an action plan to address the consequences of drought and water scarcity, and to provide advice on improving the quality of environment. One of the green infrastructure implementation programmes is the programme of the Slovak Environment Agency within the Operational Programme Quality of Environment for the period 2014-2020 (OP QE): National project - Support of Biodiversity with Green Infrastructure Elements in

Contact address: Denisa Halajová, Slovak University of Agriculture in Nitra, Faculty of Horticulture and Landscape Engineering, Department of Garden and Landscape Architecture, Tr. Andreja Hlinku 2, 94976 Nitra, 甶 +421 37641 54 22; e-mail: denisa.halajova@uniag.sk 
Municipalities of Slovakia "Green municipalities of Slovakia," which was chosen as a case study to evaluate national green infrastructure implementation projects.

\section{Material and method}

The National project - Support of Biodiversity with Green Infrastructure Elements in Municipalities of Slovakia "Green municipalities of Slovakia" was implemented between 2018 and 2020. The aim of the national project is to implement green infrastructure at a local level through vegetation and with the purpose to maintain and restore biodiversity and ecosystems outside of protected areas Natura 2000. At the local level, this will strengthen the climate, soil conservation, water protection and the landscaping function of ecosystems as well as the environmental function of the urbanized environment. The result of the "Green municipalities of Slovakia" project will be the implementation of vegetation elements at least at 390 eligible sites and the revitalization of natural and semi-natural areas and green areas in urbanized systems (Slovak Environmental Agency, 2019). Eligible users of the programme are municipalities with the designated area in their ownership and located in a currently developed municipal area.

As a part of the national programme, an implementation plan for 6 municipalities in Slovakia in 2020 was proposed. These are five municipalities in the Nitra Self-governing Region (Lužany, Tehla, Štitáre, Modrany, Slažany) and one municipality in the Banská Bystrica Self-governing Region (Čebovce). The size of municipalities that ranges from 200 to 499 inhabitants is represented by the municipalities of Lužany and Tehla, while the size of municipalities from 1,000 to 1,999 inhabitants is represented by the municipalities of Štitáre, Čebovce, Modrany and Slažany.

The implementation plan was elaborated on, on the basis of The Methodological Manual for Support of Biodiversity with Green Infrastructure Elements. The implementation project must define the place and method of implementation of the vegetation elements, the extent of the implementation and the type of vegetation elements (Urban et al., 2018). Subsequently, we evaluated the implementation plans in terms of the use of vegetation elements in different categories of green spaces, types of vegetation, representation of tree species, but also costs and benefits. Based on the results, we set the potential and limits of the programme and suggestions for its future development.

\section{Results and discussion}

\section{Categories of green spaces}

In 6 municipalities, 17 suitable localities were selected for the project, which is an average of 2.83 localities per municipality. The largest number of localities within the municipality was four, namely in three municipalities, in two municipalities only one locality was solved. The decisive criterion in the selection of the site was the ownership of the land, as the solved land must be the sole property of the municipality or under a long-term sublease. This condition is the most limiting factor for municipalities, as many do not have enough land in their ownership and therefore they do not meet the programme conditions or they can only draw funding from the programme to a very limited extent. In rural settlements there are mainly smaller areas of green spaces, so that in order to meet the project objectives, municipalities have chosen several smaller localities in their ownership. However, these green areas are not interconnected, with the exception of the municipality of Tehla (Fig. 1), where the areas will be connected by a tree alley.

In terms of categorization, among the green spaces for the project there were mostly selected semi-public green spaces, which are accessible to the public only to a limited extent, namely 10 localities, which is $59 \%$ of the designated localities. The most often represented ones were school grounds (17.64\%) and cemeteries (17.64\%), followed by sports facilities (11.76\%), and wastewater treatment plant areas (11.76\%). Areas of public green spaces accounted for $41 \%$ of the areas, most often streets (11.76\%). Overall, within the 17 objects, 10 different categories of green spaces (Table 1) were proposed.

In the selected municipalities, it was difficult to apply tree planting to public spaces, especially squares, due to the planting of trees in these areas in the recent past under other village renewal programmes. This criterion also significantly affected the resulting representation of green groups in favour of semi-public green spaces. Another problem was the impossibility of planting a tree on the streets, which is limited both by ownership relations and by the restriction of engineering networks in green belts.

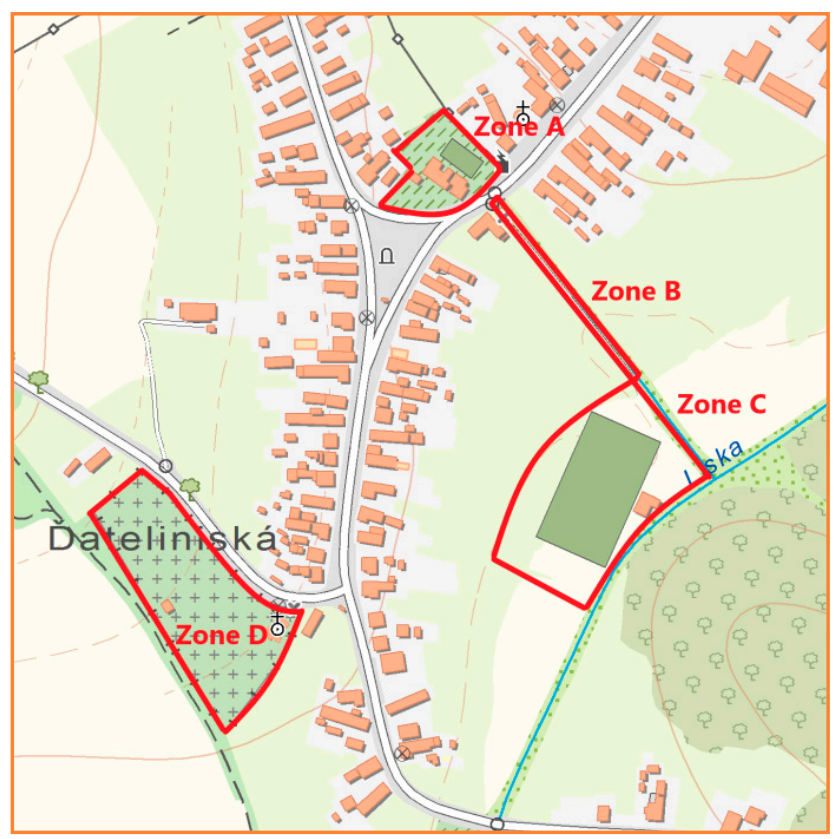

Figure 1 Scheme of functional zones of green spaces in the village Tehla

Zone A - School complex - isolation vegetation on perimeter, Zone B - Road - the tree alley, Zone C - Sports areal - isolation vegetation on perimeter, Zone D Cemetery - isolation vegetation on perimeter Map source: ZBGIS 
Table 1 Selected green spaces categories

\begin{tabular}{|c|c|c|c|c|c|c|c|c|}
\hline \multirow{2}{*}{\multicolumn{2}{|c|}{ Green spaces categories }} & \multicolumn{6}{|c|}{ Municipalities (by size from smallest) } & \multirow{2}{*}{$\begin{array}{c}\text { Total } \\
\text { category } \\
\text { no. /ha }\end{array}$} \\
\hline & & $\begin{array}{l}\text { Lužany } \\
\text { no. /ha }\end{array}$ & $\begin{array}{c}\text { Tehla } \\
\text { no. /ha }\end{array}$ & $\begin{array}{l}\text { Štitáre } \\
\text { no. /ha }\end{array}$ & $\begin{array}{c}\text { Čebovce } \\
\text { no. /ha }\end{array}$ & $\begin{array}{c}\text { Modrany } \\
\text { no. /ha }\end{array}$ & $\begin{array}{l}\text { Slažany } \\
\text { no. /ha }\end{array}$ & \\
\hline \multirow{6}{*}{$\begin{array}{l}\text { Public green } \\
\text { spaces }\end{array}$} & street & & & & & $1 / 0.44$ & $1 / 0.08$ & $2 / 0.52$ \\
\hline & square & $1 / 0.34$ & & & & & & $1 / 0.34$ \\
\hline & park, pocket park & & & & $1 / 1.08$ & & & $1 / 1.08$ \\
\hline & road & & $1 / 0.02$ & & & & & $1 / 0.02$ \\
\hline & residential zone & & & & & & $1 / 0.73$ & $1 / 0.73$ \\
\hline & residual green space & & & $1 / 0.04$ & & & & $1 / 0.04$ \\
\hline \multirow{4}{*}{$\begin{array}{l}\text { Semi-public } \\
\text { green spaces }\end{array}$} & school ground & & $1 / 0.30$ & & & $2 / 1.04$ & & $3 / 1.34$ \\
\hline & sports area & & $1 / 1.11$ & $1 / 0.08$ & & & & $2 / 1.19$ \\
\hline & cemetery & & $1 / 1.22$ & & & $1 / 2.45$ & $1 / 0.60$ & $3 / 4.27$ \\
\hline & WWTP & & & $1 / 0.29$ & & & $1 / 0.52$ & $2 / 0.81$ \\
\hline \multicolumn{2}{|c|}{ Total green spaces per municipality no. /ha } & $1 / 0.34$ & $4 / 2.65$ & $3 / 0.41$ & $1 / 1.08$ & $4 / 3.93$ & 4/ 1.93 & $17 / 10.34$ \\
\hline
\end{tabular}

Tree species representation In order to fulfil the objectives of the programme, the proposed woody plants were to be selected only from a list of precisely defined domestic woody plants species, in total 35 species, of which 29 deciduous and 6 coniferous. The selection of woody plant species was primarily dependent on climatic conditions and potential vegetation. The projects were implemented in an urbanized environment; therefore a significant criterion in the selection of trees was also their aesthetic value and other properties such as toxicity or allergenicity.

A total of 467 woody plants individuals were proposed,

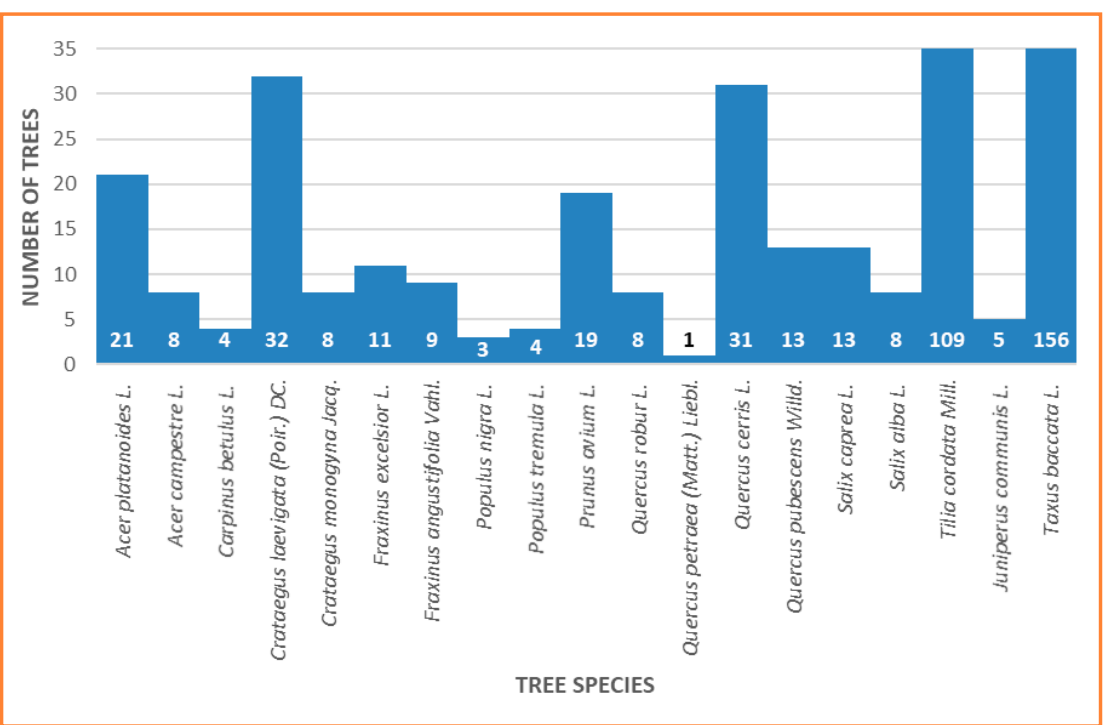

Figure 2 Summary of tree species representation in all municipalities representing a total of 19 woody plants species, of which 17 species of deciduous trees and 2 species of coniferous shrubs. The most numerous species were the coniferous shrubs Taxus baccata L. (33.40\%), and broad-leaved trees Tilia cordata Mill. (23.34\%), Crataegus laevigata (Poir.) DC. (6.85\%), Quercus cerris L. (6.64\%), Acer platanoides L. (4.50\%) and Prunus avium L. (4.07\%) (Fig. 2).

All the villages are located in areas with warm climate; therefore, native deciduous trees more resistant to drought $(65.53 \%)$ were preferred to conifers. The high abundance of Taxus baccata $\mathrm{L}$. individuals is due to the fact that it was the only shrub species in the list of recommended plants for this programme. It was necessary for the planting under existing trees (park Čebovce), or for creating evergreen vegetation along the perimeter of the areas (cemetery Slažany, park Lužany). The use of species Crataegus laevis (Poir.) DC., the only smaller tree in the list of recommended plants, was related mainly to the limited space available, but also to its flowering, which played a role in the selection of Prunus avium L., too. Both the size of the trees and their attractiveness play a major role in the urbanized environment when it comes to selecting trees.

The biggest shortcoming of the list of recommended plants appeared to be the absence of fruit trees, especially old varieties and shrubs which are needed for the restoration of alleys and small green areas in the countryside. In total, 467 tree species were proposed in 6 municipalities, which are 78 individuals per municipality, and 27 individuals per site. A minimum of 54 individuals was designed in the village of Čebovce, and a maximum of 110 individuals in the village of Slažany.

From the point of view of the greenery form, woody plants were used mainly in the form of peripheral greenery in 10 localities (58.82\%), and in the form of tree alleys in 6 localities (35.29\%). The selected forms of greenery were mainly related to the smaller size of the sites, their use, location and shape. For example, 
Table 2 Project costs

\begin{tabular}{|c|c|c|c|c|c|c|c|}
\hline \multirow[t]{2}{*}{ Economic indicators } & \multicolumn{6}{|c|}{ Municipalities (by size starting with the smallest) } & \multirow[t]{2}{*}{ Total } \\
\hline & Lužany & Tehla & Štitáre & Čebovce & Modrany & Slažany & \\
\hline Number of locations & 1 & 4 & 3 & 1 & 4 & 4 & 17 \\
\hline Area (ha) & 0.34 & 2.65 & 0.41 & 1.08 & 3.93 & 1.93 & 10.34 \\
\hline Number of trees & 59 & 86 & 70 & 54 & 88 & 110 & 467 \\
\hline Cost of plant materials $(€)$ & $2,884.14$ & $7,684.26$ & $4,212.00$ & $3,365.35$ & $7,680.58$ & $5,788.28$ & $31,614.61$ \\
\hline Planting costs $(€)$ & $5,522.40$ & $8,049.60$ & $6,552.00$ & $5,335.20$ & $8,236.80$ & $10,296.00$ & $43,992.00$ \\
\hline Total planting costs $(€)$ & $8,406.54$ & $15,733.86$ & $10,764.00$ & $8,700.55$ & $15,917.38$ & $16,084.28$ & $75,606.61$ \\
\hline
\end{tabular}

Table 3 Summary of economic indicators of the project

\begin{tabular}{|l||c|c|c|c|}
\hline \multicolumn{1}{|c|}{} & Per municipality & Per locality & Per $\mathbf{1}$ ha & Per tree \\
\hline \hline Total planting costs $(\boldsymbol{\epsilon})$ & $12,601.10$ & $4,447.44$ & $7,312.05$ & 161.90 \\
\hline Number of trees & 78 & 27 & 45 & - \\
\hline
\end{tabular}

Table 4 Greenery functions

\begin{tabular}{|l||c|c|c|c|c|c|c|}
\hline \multicolumn{1}{|c||}{ Greenery functions } & \multicolumn{7}{c|}{$\begin{array}{c}\text { Number of locations } \\
\text { Municipalities (by size starting with the smallest) }\end{array}$} \\
\cline { 2 - 10 } & \multirow{2}{*}{ Lužany } & Tehla & Štitáre & Čebovce & Modrany & Slažany \\
\hline Climate & 1 & 4 & 3 & 1 & 4 & 4 & 17 \\
\hline Landscape & 1 & 4 & 2 & 1 & 2 & 2 & 12 \\
\hline Urban environmental & 1 & 3 & 1 & 1 & 4 & 2 & 12 \\
\hline Water protection & & 2 & 1 & & & 1 & 4 \\
\hline
\end{tabular}

for school and sports facilities grounds with a building or playground in the middle, it was not possible to use greenery in other forms than at the perimeter of the areas.

\section{Costs and benefits of the project}

The project conditions set the minimum value of the project implementation $(8,400 €$ incl. VAT) as well as the maximum value of the project implementation $(16,500 €$ incl. VAT). The total cost of planting and materials together accounted to an average of $€ 12,601.10$ per municipality, $€ 7,312.05$ per ha of area, and $€ 161.90$ per single tree. The average number of trees per ha was 45 individuals, 27 individuals for one locality, and 78 trees for one municipality (Table 2 and Table 3). The total cost included precisely specified plant materials meeting the relevant standards, professional planting and subsequent monitoring of trees during the project period. To evaluate the success of the project, it was necessary to recalculate the costs of tree planting according to the number of survived trees, 3 years after planting.

Naumann et al. (2011) indicated a wide range of per hectare costs for different green infrastructure projects, with capital costs ranging from $€ 250$ to almost $€ 1$ million per hectare and also indicated some general conclusions: per hectare costs tend to be low for restoration of very extensive habitats, and high for very intensive restoration works targeting small parcels of land. The finding that per hectare costs decline with site size is typical of nature conservation projects. Restoration of urban parks and green spaces tends to have very high costs per ha, especially when this involves working on buildings and gardens. From this point of view, we can classify the project as a relatively less expensive project.

The benefits of green infrastructure can be measured in different ways and at different levels and may be assessed by examining different indicators, for example by ecosystem services (European Commission, 2012). The results of the programme do not yet provide measurable indicators of the benefits of green infrastructure elements. The programme lists the functions whose improvement and fulfilment are expected as a result of the project for each site being solved: to strengthen the climate, soil conservation, water protection and landscape function of ecosystems as well as the urban environmental function. In the selected areas it will be possible to strengthen the climatic function at $100 \%$ (17) areas, landscaping function and the environmental function at $70.59 \%$ (12) areas and water protection function at $53 \%$ (4) of areas (Table 4).

\section{Conclusions}

Rural municipalities $(2,749)$ make up $93.92 \%$ of municipalities in Slovakia. An essential element of green infrastructure, especially in all conventional green components, is a tree. The design-relevant and health-promotional effects of trees combined together with their ecological and economic importance justify their planting, maintenance, and relational perception (Frohman, 2020). Therefore 
The National project - Support of Biodiversity with Green Infrastructure Elements in Municipalities of Slovakia with the aim to promote tree planting in rural municipalities can be considered an important tool for the creation of green infrastructure throughout Slovakia. Another project's positive aspect relates to the development of a professional methodological manual for the benefit of professionally qualified persons. Negative aspects of the programme would be assessed upon completion of the program, after having monitored the trees for a few years. The maintenance of trees in the future is perceived as a potential risk, as it might not be sufficiently financially covered, especially in smaller municipalities with lower budgets. Lack of professional maintenance is already evident after the first few years considering the number of survived trees, and their poor health conditions. Another potential risk of the project may be the aesthetic criterion and the functionality of the proposed trees, as this programme does not deal with concepts such as landscape or village image, village character and identity, but focuses significantly only on improving biodiversity and greenery functions. Some limits of the project include a restricted selection of tree species without the possibility of using, for instance, fruit trees or deciduous shrubs. In the case of project continuation, future implementation should be directed towards the professional maintenance of existing trees, in addition to new tree planting. It would also be appropriate to quantify the benefits of these types of projects, and compare them with the actual costs of the project.

\section{References}

EUROPEAN COMMISSION. 2012. The Multifunctionality of Green Infrastructure. Retrieved from https://ec.europa.eu/environment/ nature/ecosystems/docs/Green_Infrastructure.pdf

EUROPEAN COMMISSION. 2013. Communication from the Commission to the European Parliament, the Council, The European Economic and Social Comittee and the Committee of the Regions, Green Infrastructure (GI) - Enhancing Europe's Natural Capital. Retrieved from https://eur-lex.europa.eu/resource. html? uri=cellar:d41348f2-01 d5-4abe-b817-4c73e6f1 b2df.0014.03/ DOC 1\&format=PDF

FROHMMAN, E. 2020. Trees in the City - Perception and Aesthetic Expression. In Plants in Urban areas and Landscape, 2020, no. 2, pp. 3-9. https://doi.org/10.15414/PUAL/2020.3-9

NAUMANN, S. - McKENNA, D. - KAPHEGST, T. - PIETERSE, M. RAYMET, M. 2011. Design, implementation and cost elements of Green Infrastructure projects. Final report. Retrieved from https:// ec.europa.eu/environment/enveco/biodiversity/pdf/GI DICE FinalReport.pdf

SLOVAK ENVIRONMENT AGENCY. 2019. General Conditions to provide support within the national project Support of biodiversity by elements of green infrastructure in municipalities of Slovakia Green municipalities of Slovakia. Retrieved from http://www. zeleneobce.sk/VP 012018 ZoNFP2.pdf

URBAN, P. - JASENKA, M. - KUBINSKÝ, D. - KOLEDA, P. ŽONCOVÁ, M. - GREGOROVÁ, B. - BAČKOR, P. - ŠEMBERA, I. 2018. Methodological guide to promoting biodiversity with green infrastructure elements - Support of biodiversity by elements of green infrastructure in municipalities of Slovakia - Green municipalities of Slovakia. Retrieved from http://www.zeleneobce. sk/odborna-metodicka-prirucka-zelene-obce.pdf

TÓTH, A. - HALAJOVÁ, D. - HALAJ, P. 2015. Green Infrastructure: A Strategic Tool for Climate Change Mitigation in Urban Environments. In Ecology and Safety, 2015, no. 9, pp. 132-138. 